\title{
Erscheinungsjahr und Umfang
}

\begin{tabular}{ccc|ccc} 
Archiv-Bd. & Erscheinungsjahr & Umfang & Archiv-Bd. & Erscheinungsjahr & Umfang \\
1 & 1876 & 644 & 22 & 1900 & 642 \\
2 & 1877 & 764 & 23 & 1901 & 643 \\
3 & 1879 & 763 & 24 & 1902 & 645 \\
5 & 1880 & 735 & 25 & 1903 & 659 \\
4 & 1881 & 712 & 26 & 1904 & 644 \\
6 & 1882 & 765 & 27 & 1905 & 640 \\
7 & 1884 & 737 & 28 & 1906 & 646 \\
8 & 1885 & 676 & 29 & 1907 & 644 \\
9 & 1886 & 710 & 30 & 1909 & 640 \\
10 & 1887 & 672 & 31 & 1910 & 663 \\
11 & 1888 & 646 & 32 & 1911 & 656 \\
12 & 1890 & 646 & 33 & 1912 & 660 \\
13 & 1891 & 640 & 34 & 1913 & 649 \\
Supplementbd. & 1892 & 4151 & 35 & 1914 & 646 \\
14 & 1892 & 643 & 36 & 1916 & 635 \\
15 & 1893 & 642 & 37 & 1920 & 560 \\
16 & 1894 & 640 & 38 & 1923 & 292 \\
17 & 1895 & 640 & 39 & 1925 & 304 \\
18 & 1896 & 640 & 40 & 1926 & 322 \\
19 & 1897 & 644 & 41 & 1927 & 324 \\
20 & 1898 & 651 & 42 & 1929 & 321 \\
21 & 1899 & 644 & & &
\end{tabular}

1) F. Pastrnek, Bibliographische Ubersicht über die slavische Philologie 1876-1891. Zugleich Generalregister zu Bd. 1-13. 